\title{
Design and Fabrication of Remote Welding Equipment in a Hot-Cell
}

\author{
Soosung Kim, ${ }^{1}$ Kihwan Kim, ${ }^{1}$ Jungwon Lee, ${ }^{1}$ and Jinhyun Koh ${ }^{2}$ \\ ${ }^{1}$ Research Reactor Fuel Development Division, Korea Atomic Energy Research Institute, Yuseong-gu, \\ Daejeon 305-353, Republic of Korea \\ ${ }^{2}$ Korea University of Technology and Education, Cheonan 330-708, Republic of Korea \\ Correspondence should be addressed to Soosung Kim; sskim7@kaeri.re.kr
}

Received 6 May 2013; Revised 26 September 2013; Accepted 26 September 2013

Academic Editor: Arkady Serikov

Copyright (C) 2013 Soosung Kim et al. This is an open access article distributed under the Creative Commons Attribution License, which permits unrestricted use, distribution, and reproduction in any medium, provided the original work is properly cited.

\begin{abstract}
The remote welding equipment for nuclear fuel bundle fabrication in a hot-cell was designed and developed. To achieve this, a preliminary investigation of hands-on fuel fabrication outside a hot-cell was conducted with a consideration of the constraints caused by the welding in a hot-cell. Some basic experiments were also carried out to improve the end-plate welding process for nuclear fuel bundle fabrication. The resistance welding equipment using end-plate welding was also improved. It was found that the remote resistance welding was more suitable for joining an end-plate to end caps in a hot-cell. This paper presents an outline of the developed welding equipment for nuclear fuel bundle fabrication and reviews a conceptual design of remote welding equipment using a master-slave manipulator. Furthermore, the mechanical considerations and a mock-up simulation test were described. Finally, its performance test results were presented for a mock-up of the remote resistance welding equipment for nuclear fuel bundle fabrication.
\end{abstract}

\section{Introduction}

Fuel cycle technology is being developed at KAERI and is meant to reuse spent PWR (Pressurized Water Reactor) fuel as raw material for the CANDU reactor [1]. This technology is being developed in the IMEF (Irradiated Material Examination Facility) at KAERI because of the nature of the high radioactivity of spent PWR fuel. In order to fabricate DUPIC (Direct Use of PWR fuel In CANDU reactors) nuclear fuels in a hot-cell environment, remote welding technology should be employed to weld between an end-plate and an end cap. To achieve this, a preliminary investigation of a hands-on fuel fabrication outside a hot-cell was necessary in consideration of the constraints caused by remote welding in a hot-cell [2]. The DFDF (DUPIC Fuel Development Facility) is a completely shielded cell made of heavy concrete. As the DFDF is active, direct human access to its inner cell is not possible. All the nuclear fuel fabrication processes and equipment operations, therefore, are conducted in a fully remote manner, using a master-slave manipulator.

In order to select a more suitable welding process in a hotcell environment, various welding processes such as GTAW
(Gas Tungsten Arc Welding), RW (Resistance Welding) [3], and LBW (Laser Beam Welding) methods, which are now available for end-plate welding for the commercial fuel bundle fabrication, should be processed as candidates. Even though the GTAW process is widely used for fabricating fuel bundles, it cannot be recommended for remote end-plate welding of a nuclear fuel bundle in a hot-cell facility due to the complexity of electrode alignment and difficulty in parts replacement in a remote manner. On the other hand, the RW process has some advantages because it is a qualified process and is extensively used in production. Hence, remote welding equipment was needed in order to join end-plates to end caps in a remote manner. The objective of this paper is to present the development of nuclear fuel bundle welding equipment for use in the highly radioactive zone of the DFDF at KAERI.

\section{Design of Remote Welding Equipment}

All equipment for the remote fabrication of the nuclear fuel elements will be installed in a hot-cell as shown in Figure 1. As long as commercial equipment is available, it is purchased 


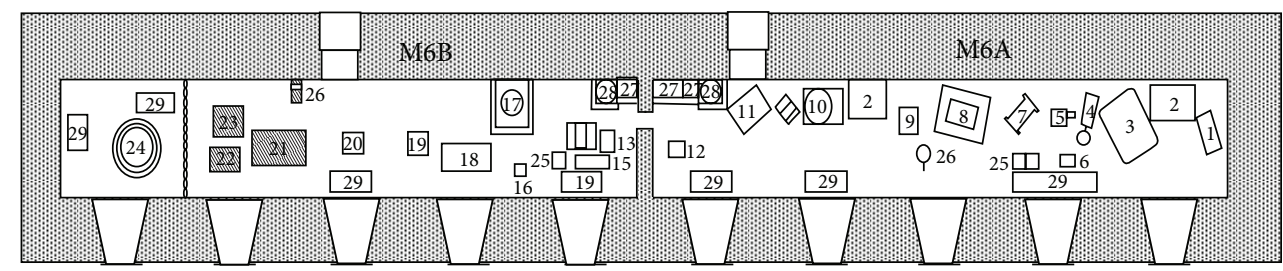
(1) Mill
(2) Off-gas treatment system
(3) Oreox furnace (oxidation and dewaxing)
(4) Mixer
(5) Slitting machine
(6) Powder QC equipment
(7) Compaction press
(8) Centerless grinder
(9) Cutter
(10) Sintering furnace

(11) QC-furnace

(12) Pellet cleaner/dryer

(13) Pellet loading machine

(14) Pellet QC equipment

(15) Pellet stack adjuster

(16) Rod QC equipment

(17) S/G-DSNC

(18) End cap welder

(19) Helium leak tester

(20) Minielement assembly machine
(21) End plate welder

(22) Bundle QC equipment

(23) Bundle cleaner

(24) Decon. chamber

(25) Balance

(26) Vacuum cleaner

(27) Material storage

(28) Waste storage

(29) Ventilation filter

Equipment for bundle fabrication

FIGURE 1: Layout of the remote process equipment for nuclear fuel fabrication in DFDF.

Outer cell

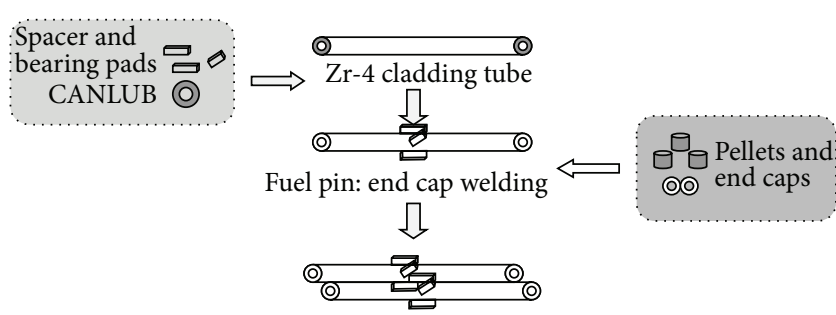

Fuel pins: fixture and assembling

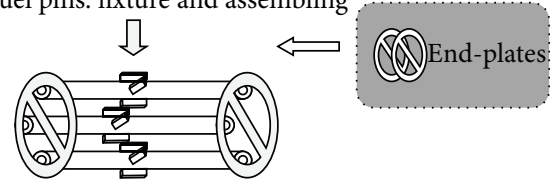

Fuel bundle: end-plate welding

FIGURE 2: Process of end-plate welding operation and handling.

and modified for hot-cell use from the viewpoint of easy remote operation and maintenance. Among them, the remote welding equipment was designed to be modular and remotely operable by using a master-slave manipulator as shown in Figure 1 (No. 21). The main parts of the welding equipment are located inside a hot cell, while the electronic parts are separated for installation outside a hot cell. The remote welding equipment is developed by adopting a head torch in order to achieve spot weld metal between an end-plate and end caps using a master-slave manipulator. As for endplate welding operation and handling in a remote manner as shown in Figure 2, the design concept should take into account the remote manipulation, welding procedure, and capabilities and constrains of the remote handling devices that are available in a hot-cell. The design should also include considerations of an interface with a human operator, modular assembling parts for easy maintenance, electrical power transmission for control, and radiation effects of the materials to be used.
The remote welding system of the hot-cell environment consists of a resistance welding equipment, master-slave manipulator, and controller. The main head of the welding equipment will be used through a multi-pulse type method [4]. The modular remote welding equipment for a fuel bundle fabricating in a hot-cell was made by upgrading the design of the previous welding equipment for multipin fuel types. In this fabricating process sequence of fuel bundles, the fuel elements welded by the end caps were first positioned in an assembly fixture, in which the top part of a fuel bundle was welded. Finally, the bottom part of the fuel bundle after rotating $180^{\circ}$ was welded to the bottom end-plate. In this process, a master-slave manipulator was required to be designed and assembled to be handled easily because the remote operation using a slave manipulator in a hot-cell was carried out. The modular welding equipment made up of four subassembly parts was designed with a modular concept and is compact in comparison with a previous welder for multipin fuel types in a remote manner.

The remote welding equipment consists of a main frame, a weld head using a single electrode, a branch electrode indexer, an endplate magazine loader, and a bottom assembler [5-7]. Figure 3 show the basic concept of the welding equipment, and Figure 4 illustrates the design construction of the remote welding equipment. The base frame itself consists of a single $\mathrm{W}-\mathrm{Cu}$ electrode, a step-down transformer, an air cylinder, or other means of applying a change of the $\mathrm{W}-\mathrm{Cu}$ electrode using a head pin as shown in Figure 4(a). A branch electrode indexer provides accurate rotation of the upper and lower fuel bundle during end-plate welding operations. A rotary indexer driven by the servo motor is adjustable to allow the length of the overall shafting to vary as the indexing units are raised and lowered. The shafting for a remote operation is fitted together by means of a linear guide and linear bearing slides. A jigging plate using the $\mathrm{Be}-\mathrm{Cu}$ branch electrodes, as shown in Figure 4(a), provide an accurate seat for the bundle endplates and 37 elements. This part aligns the $\mathrm{W}$-Cu electrode 


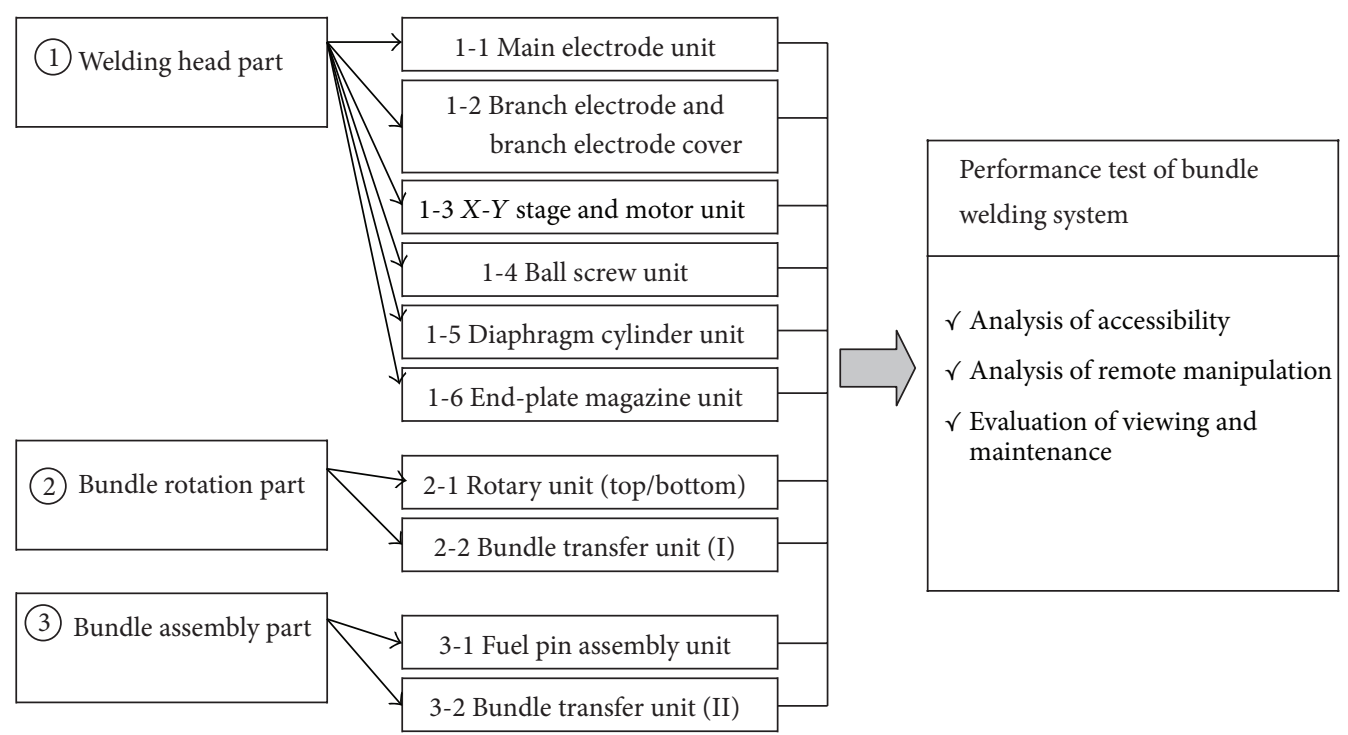

FIgURE 3: Basic concept of the remote welding equipment.

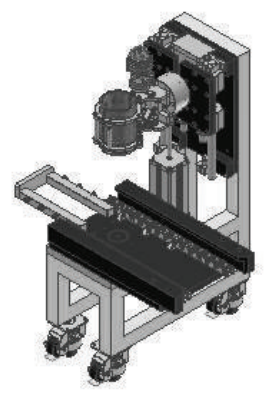

(b)

(a) Weld head part:

Main electrode unit

Main frame unit

Branch electrode unit

$X-Y$ stage unit

End-plate magazine unit

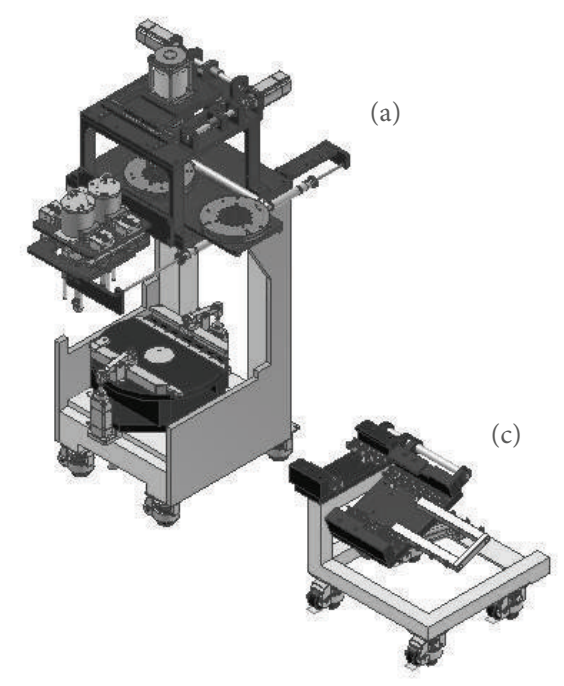

(b) Bundle rotation part: Bundle rotation unit Vertical transfer unit

(c) Bundle assembly part:

Fuel elements assembly

Angle control unit

Bundle transfer unit

FIGURE 4: Design construction of remote welding equipment.

with the ends of 37 elements during a welding operation. Endplate loading mechanisms were used for the upper and lower units. An end-plate magazine loader as shown in Figure 4(a), dispenses and loads either the upper or lower end-plates to the bundle welding operation. A reloadable magazine provides the supply of end-plates to the units, which are dispensed one at a time by an air cylinder. A tuner unit of a bottom assembler was incorporated into the end-plate transfer gripper tooling to execute the rotation of the endplate required during transfer, as shown in Figure 4(b). This 


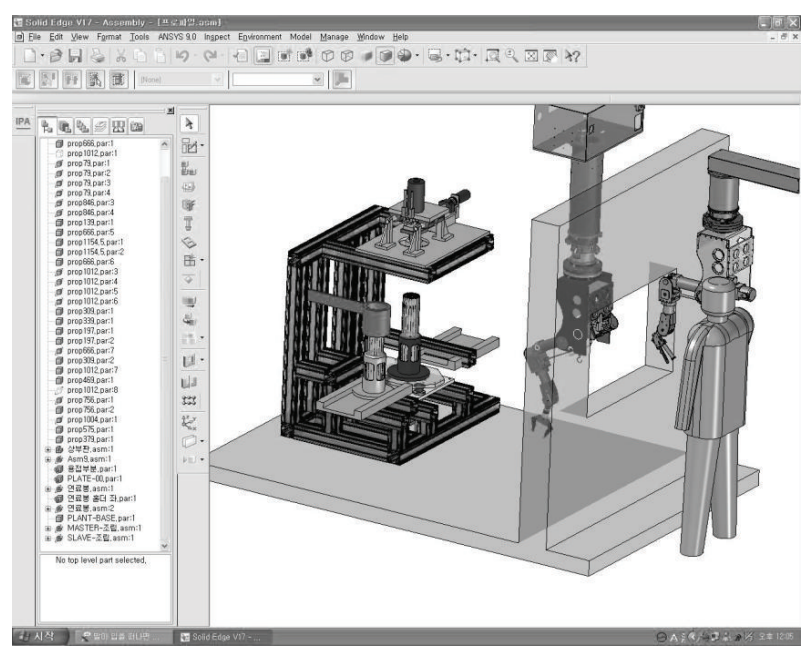

Figure 5: Schematic of remote welding system using by ProEngineer design method.

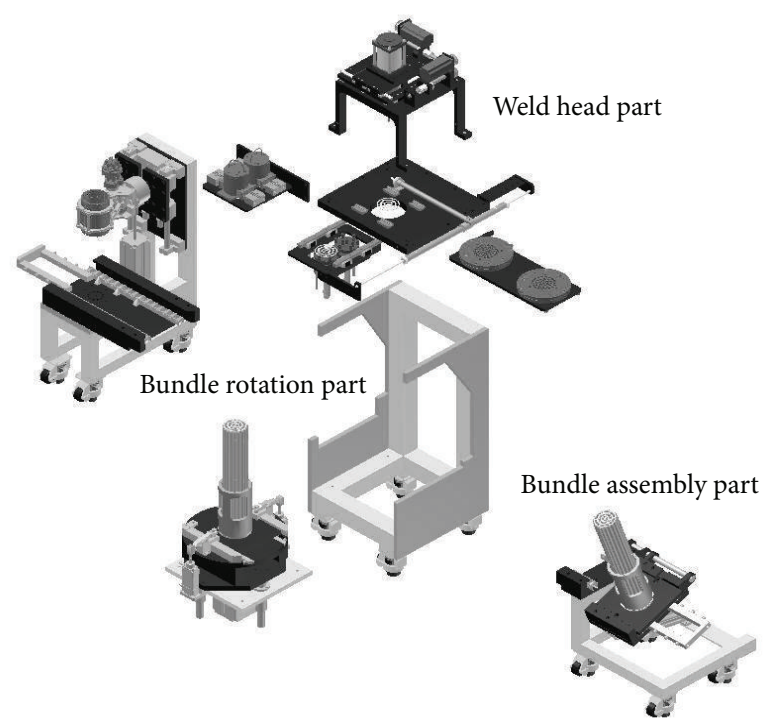

FIGURE 6: Auxiliary exploded and reassembled functions of top assembler.

unit is very robust, and thereby adheres to the permissible load restrictions of requiring no maintenance. Each of these subassembly parts of the remote welding equipment was designed in modules to facilitate maintenance by remote manipulation.

\section{Result and Discussion}

3.1. Mock-up Tests Using Remote Welding Equipment. After completing a basic drawing for the remote welding equipment, as shown in Figure 5, a design of the modular remote welding equipment was conducted by making a structural configuration and developing with the Pro-Engineer Wildfire 3.0 program produced by PTC (Parametric Technology Corporation). Based on the modular design, the remote

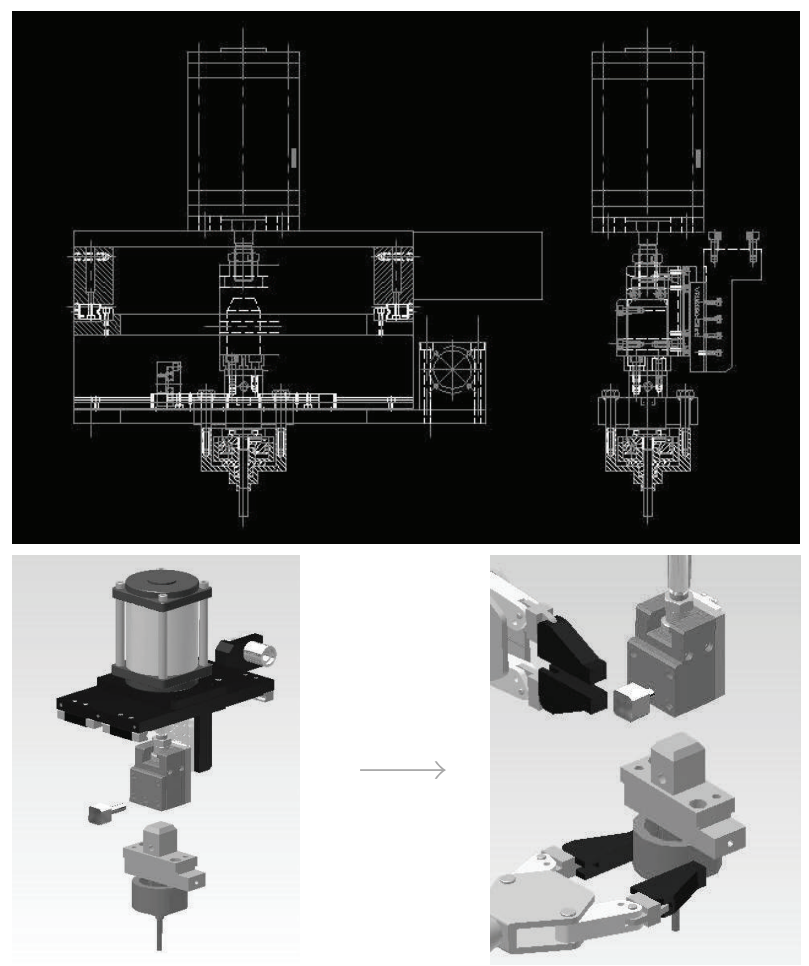

FIGURE 7: Illustration of designing, installing, and exchanging weld head.

operation in a hot-cell using the manipulator was checked with the aid of auxiliary exploded and re-assembled functions along with animations using the Pro-Engineer design method shown in Figure 6. The installing and exchanging of main parts such as a damaged weld head using a W-Cu electrode and $\mathrm{Be}-\mathrm{Cu}$ branch electrodes for remote operation in a hotcell, as shown in Figure 7, were also checked and analyzed. All the modular components of the assembling parts can also be remotely exchanged or maintained. In order to prevent the weld head part from dropping from the master-slave manipulator during remote operation, the weld head part uses an assistant gripper. The assistant gripper is connected by using the crane of the roof door. As with real operation, the maximum weight that the master-slave manipulator can grasp is about $6 \mathrm{~kg}$, at which point the operator can feel that the weight of the weld head part is about $1.7 \mathrm{~kg}$. A mock-up simulation test was also carried out to check technological issues for remote operation and each element for the processing sequence. It was confirmed that the mockup simulation test showed the process sequence and remote welding operation in a hot-cell environment using animation with the Pro-Engineer design method.

In order to investigate weld performance of the fabricated welding equipment in a mock-up test room, a special fixture for a weld performance test was designed and fabricated as shown in Figure 8. These weld performance tests using a special fixture were performed according to the quality control procedure (Doc. No. HQP-33-02), and the weld samples were provided for four specimens (inner and outer rod specimens No. $=12,16,31,37)$ [8]. The torque strengths 
TABLE 1: Resistance welding conditions of the weld performance test.

\begin{tabular}{lccc}
\hline Sample no. & Weld current $(\mathrm{A})$ & Pressure of main electrode (Bar) & Pressure of branch electrode (Bar) \\
\hline$\# 01$ & 4200 & 3.5 & 5.5 \\
$\# 02$ & 4200 & 4.0 & 5.5 \\
$\# 03$ & 4200 & 4.5 & 5.5 \\
$\# 04$ & 4200 & 5.0 & 4.5 \\
\hline
\end{tabular}

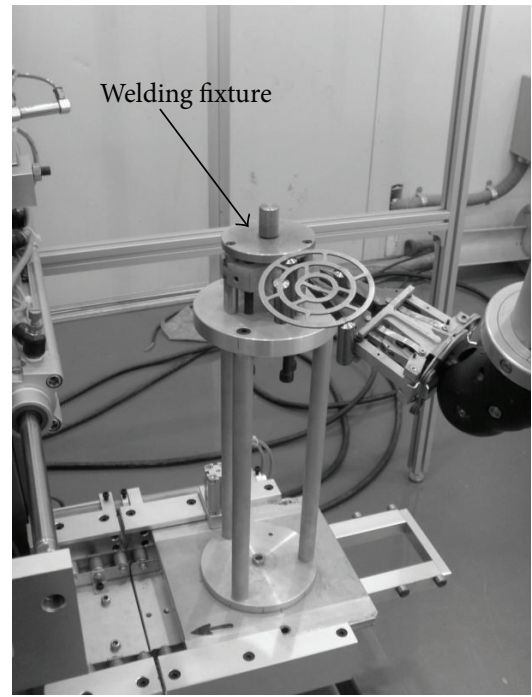

Figure 8: Photograph of the welding fixture using Zircaloy-4 weld specimen.

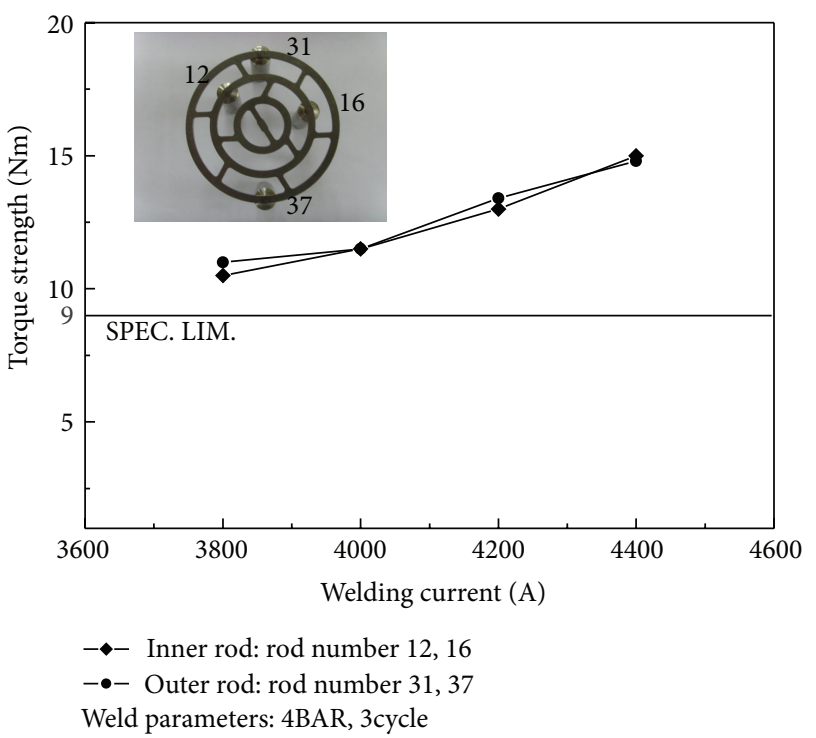

FIGURE 9: Torque strength of the welded specimens as a function of the weld current.

of the weld performance test were created by the average values of four weld specimens as shown in Figure 9. In the real experiment, a special fixture was installed on the assembly floor of the remote welding equipment and the operator performed the welding operation by handling the master slave manipulator. This experiment was carried out by

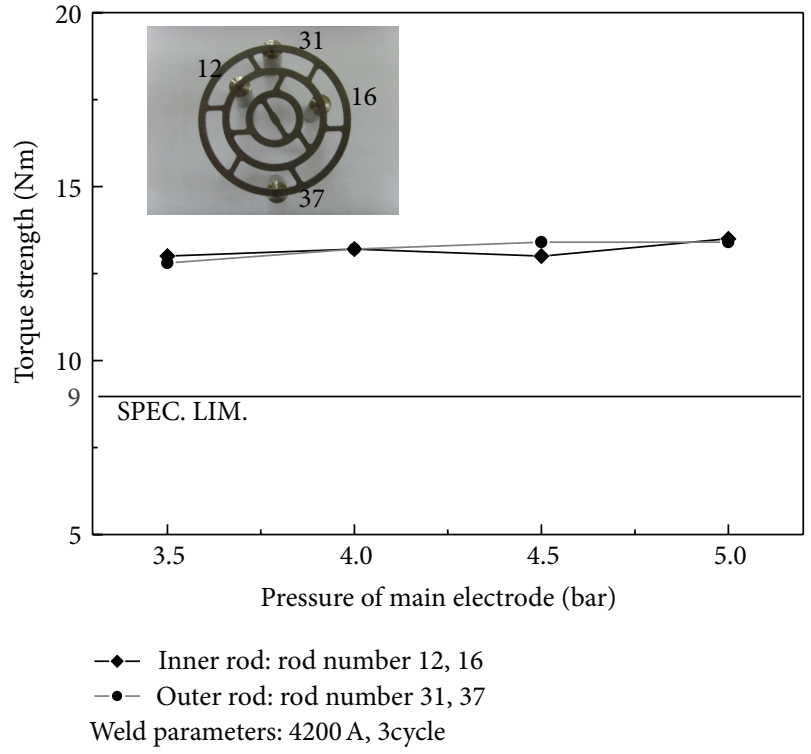

FIgURE 10: Torque strength of the welded specimens as a function of the pressure of main electrode.

varying the working parameters of the weld current and the pressure of the main electrode, while the welding sequence controlled by the operator is constant [9]. Table 1 shows the welding conditions for the weld performance test and experimental results. The experimental results show that the weld current and pressure of main electrode influence the extent of the torque strength. Figure 9 shows the relationship between the weld current and torque strength using the Zircaloy-4 weld specimens. As for the effect of the torque strength during the welding operation, it was found that the torque values increased by increasing the weld current. Figure 10 shows the relationship between the pressure of the main electrode and torque strength of the Zircaloy- 4 welded specimens at a current of $4200 \mathrm{~A}$. To the extent of 3.5 BAR to $5 \mathrm{BAR}$ of the pressure of the main electrode, the torque strengths of Zircaloy- 4 welded specimens are found to be approximately $13-14 \mathrm{Nm}$, which is larger than that of the acceptable criteria $(9 \mathrm{Nm})$ as followed by the quality control procedure. It is concluded from the experiment that for the welding conditions of the weld current and pressure of the main electrode, the torque strength reaches $99.9 \%$ in accomplishing perfect values of the resistance of Zircaloy4 welded specimens. Figure 11 shows a photomicrograph of typical weld nuggets of the end-plate joint at magnification of $\times 15$. The lower portions of the micrograph show the weld zones of end cap joint which consist of inner rod and outer rod, welded to the end-plate joint for fuel element fabrication. 


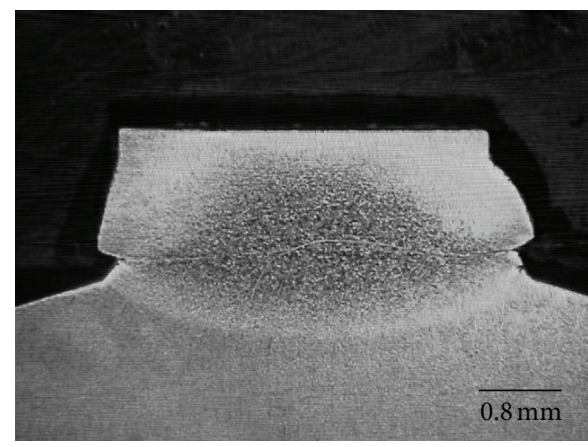

3800 A 4 bar 3 cycle $(\times 15)$

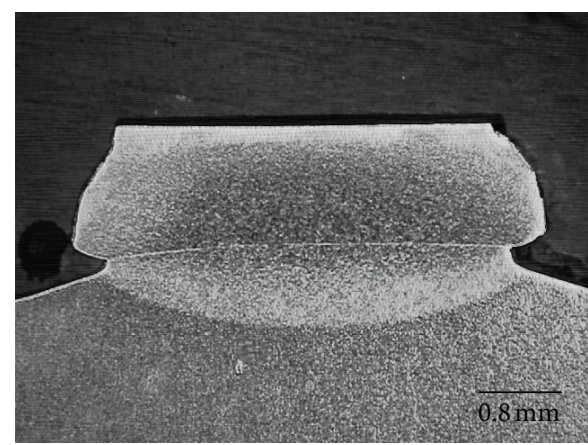

4200 A 4 bar 3cycle $(\times 15)$

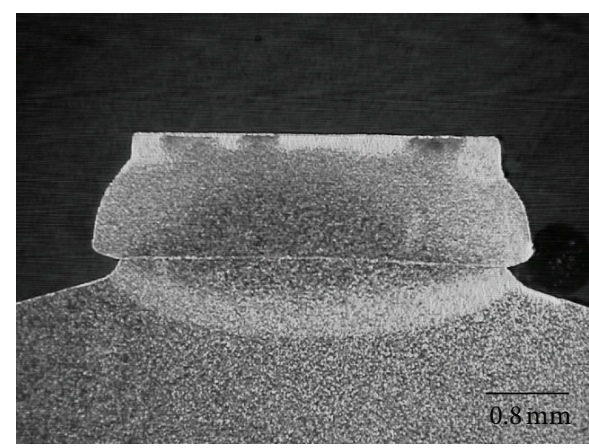

4000 A 4bar 3cycle $(\times 15)$

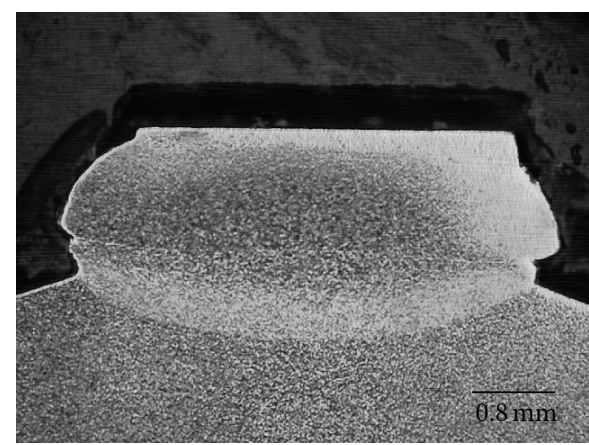

4400 A 4 bar 3cycle $(\times 15)$

Figure 11: Macrocross sections of the nugget welds in end-plate to end cap joint $(\times 15)$.

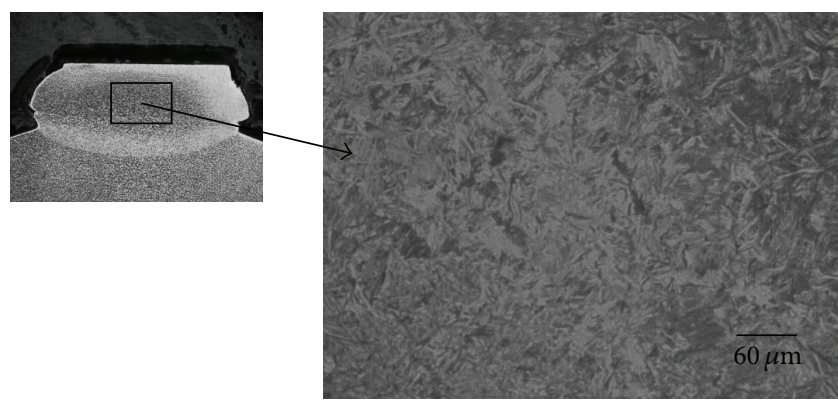

FIGURE 12: Microstructure of the central region of weld metal corresponding to part of the end-plate $(\times 500)$.

The microstructure of a weld nugget consisted of a few recrystallized and a little grown grains around an interface depending upon the heat cycles reached during the resistance welding. The weld metal of an end-plate region as shown in Figure 12 had a Widmanstätten structure with nonparallel $\alpha$ plates and was a basket-weave type [10]. The weld metal of an end cap region was also composed of a mixed structure of nonparallel Widmanstätten plates and quenched martensitic structures due to the very rapid heating and cooling cycle of the resistance welding $[10,11]$.

3.2. Simulation Tests in Mock-up Facility. The remote welding equipment has been tested to verify its performance and capabilities in a mock-up of the simulation test room. The mock-up test environment of a remote welding equipment for

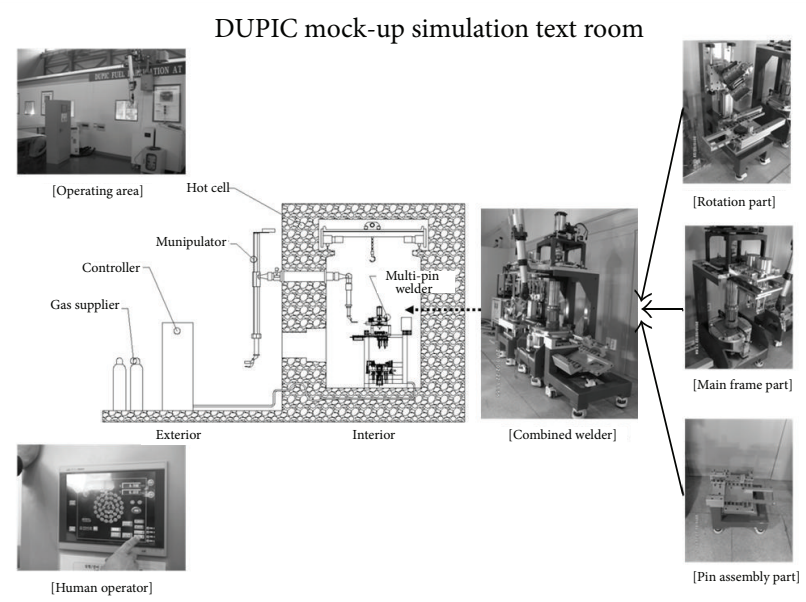

FIGURE 13: Remote welding equipment and its operation in mock-up facility.

the in-cell operation is shown in Figure 13. The human operator and manipulation are located outside of the mock-up of the simulation test room, and remote welding equipment is located inside it. Through the design and fabrication of remote welding equipment, Figure 13 shows combined welding equipment including the main frame part, the rotation part and the element assembly part in the mock-up simulation test room. Among them, the weld head of the main frame part is designed, and there is a reason why it was very interchangeable. Figure 14 illustrates remote operations using 
TABLE 2: Results of a performance test for a remote welding equipment.

\begin{tabular}{|c|c|c|c|c|c|}
\hline \multirow{2}{*}{ Main parts } & \multirow{2}{*}{ Subassembly parts } & \multicolumn{4}{|c|}{ Performance tests } \\
\hline & & Access ability & $\begin{array}{l}\text { Master-slave } \\
\text { manipulation }\end{array}$ & $\begin{array}{l}\text { Replacement of } \\
\text { sub-parts }\end{array}$ & $\begin{array}{c}\text { Repeatability } \\
\text { (technical lessons }{ }^{*} \text { ) }\end{array}$ \\
\hline \multirow{7}{*}{ (1) Head part } & 1-1 main electrode unit & $\mathrm{O}$ & $\mathrm{O}$ & $\mathrm{O}$ & $\mathrm{O}$ \\
\hline & 1-2 branch electrode unit & $\mathrm{O}$ & $\mathrm{O}$ & $\mathrm{O}$ & $\mathrm{O}$ \\
\hline & $1-3 X-Y$ stage unit & $\triangle$ & $\triangle$ & $\triangle$ & $\triangle$ \\
\hline & 1-4 servo-motors & $\triangle$ & $\triangle$ & $\triangle$ & $\triangle$ \\
\hline & $1-5$ ball screw unit & $\triangle$ & $\triangle$ & $\triangle$ & $\triangle$ \\
\hline & 1-6 diaphragm cylinder & $\triangle$ & $\triangle$ & $\triangle$ & $\triangle$ \\
\hline & 1-7 end-plate magazine box & $\triangle$ & $\triangle$ & $\triangle$ & $\triangle$ \\
\hline \multirow{2}{*}{ (2) Rotation part } & 2-1 bundle rotary unit & $\mathrm{O}$ & $\mathrm{O}$ & $\mathrm{O}$ & $\mathrm{O}$ \\
\hline & 2-2 bundle transfer unit (I) & $\mathrm{O}$ & $\mathrm{O}$ & $\mathrm{O}$ & $\mathrm{O}$ \\
\hline \multirow{2}{*}{ (3) Elements assembly part } & 3-1 fuel elements assembler & $\mathrm{O}$ & $\mathrm{O}$ & $\mathrm{O}$ & $\mathrm{O}$ \\
\hline & 3-2 bundle transfer unit (II) & $\mathrm{O}$ & $\mathrm{O}$ & $\mathrm{O}$ & $\mathrm{O}$ \\
\hline
\end{tabular}

${ }^{*}$ This is to be required in order to acquire its reliability and stability of remote welding equipment.

O: (Good), $\triangle$ : (Medium), $\times$ : (Bad).

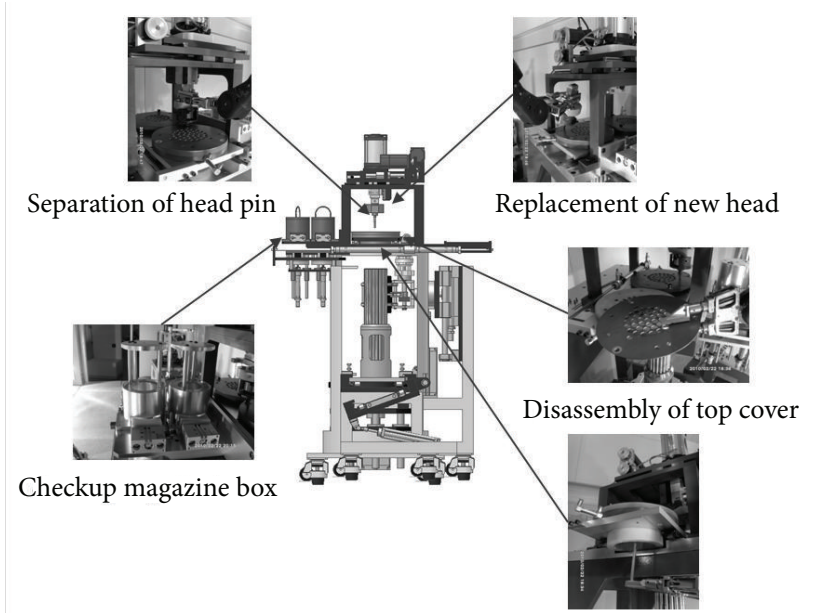

Separation of branch electrode

FIGURE 14: Illustration of manipulating various main parts.

the master-slave manipulator. The mock-up performance test using remote welding equipment shows satisfactory results in access ability, master-slave manipulation, the replacement of subassembly parts, and operation repeatability, as shown in Table 2. Currently, the weld head and branch electrode parts are under performance tests in order to determine their reliability and stability before put into the DFDF. From the mock-up test, the remote welding equipment is improved and implemented to verify its performance and capabilities of all assembly parts. The mock-up tests including functional connections of the welding equipment for the bundle endplate welding operation where a real operation though the hot-cell window is controlled using the remote and automatic process mode, are under development at the simulation test room.

\section{Conclusion}

This work was conducted to develop the remote welding equipment for nuclear fuel bundle manufacturing and to review the basic drawing by means of the Pro-Engineer design method. In the future, the optimum welding equipment and detailed drawings obtained in this study will be applied to the end-plate welding process. A performance test using remote welding equipment shows satisfactory results in access ability, master-slave manipulation, and the replacement of some parts. Furthermore, to establish the reliability of remote operations using resistance welding equipment, it was necessary to carry out a welding sample test using the end-plates for nuclear fuel bundle manufacturing in a mockup facility.

\section{Acknowledgments}

This research was supported by the Development of key technologies for Research Reactor Fuel Development sponsored by the Ministry of Education, Science and Technology (MEST) and by a grant from the Fundamental R\&D program from Core Technology of Materials Funded by the Ministry of Knowledge Economy (MKE), Republic of Korea.

\section{References}

[1] M. S. Yang et al., DUPIC Manufacturing and Process Technology, KAERI-1022/99, 2000.

[2] J. D. Sullivan, The 10th KAIF/KNS Annual Conference, 1995.

[3] L. M. Gourd, Principles of Welding Technology, Edward Arnold Publishers, 1980.

[4] American Welding Society (AWS), Welding Handbook, vol. 3, 9th edition, 2007.

[5] M. Malberg and N. Bay, "Methods of characterizing electrical systems of resistance welding machines," Welding Journal, vol. 77, no. 4, pp. 59-62, 1998.

[6] R. J. Bowers, C. D. Sorensen, and T. W. Eagar, "Electrode geometry in resistance spot welding," Welding Journal, vol. 69, no. 2, p. 45S, 1990.

[7] GE Canada Nuclear Products: Bundle Assembly Welder Manual, KNFC Equipment Data Book, 1995.

[8] S.-S. Kim, G.-I. Park, J.-W. Lee, and J.-H. Koh, "Development of a remote welding machine for a dupic fuel bundle fabrication," 
in Proceedings of the 17th International Conference on Nuclear Engineering (ICONE '09), pp. 1-8, bel, July 2009.

[9] S. S. Kim, J. W. Lee, G. I. Park, and J. H. Koh, "Development of zircaloy-4 endplate welding technology for a DUPIC fuel bundle assembly," Journal of Nuclear Science and Technology, vol. 46, no. 2, p. 103S, 2009.

[10] R. A. Bordoni and A. M. Olmedo, "Microstructure in the weld region in seam welded and resistance welded Zircaloy 4 tubing," Journal of Materials Science, vol. 16, no. 6, pp. 1527-1532, 1981.

[11] R. A. Holt, W. Evans, and B. A. Cheadle, Role of Zirconium Alloy Metallurgy in the Fabrication of Candu Fuel, Atomic Energy of Canada Limited. AECL-5107, 1975. 


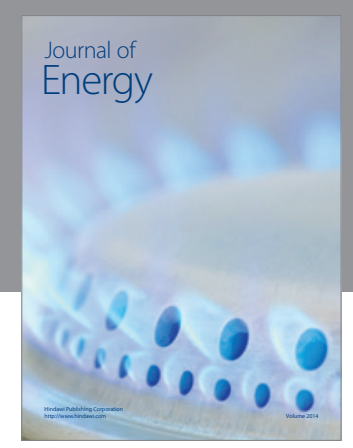

Journal of

Industrial Engineering
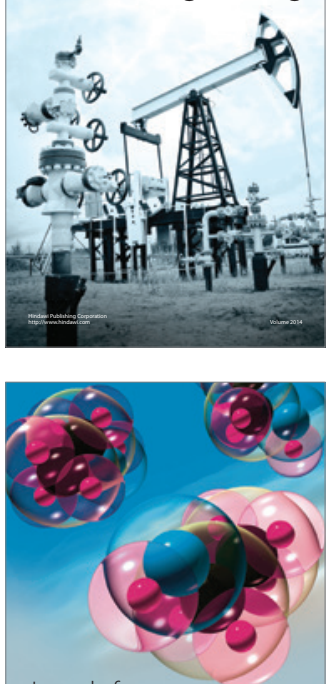

Fuels
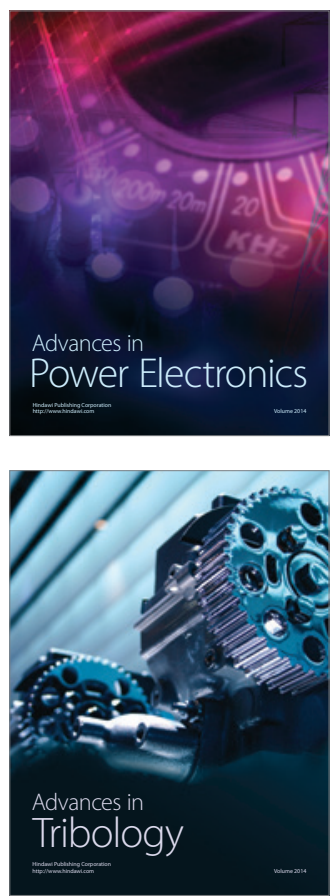

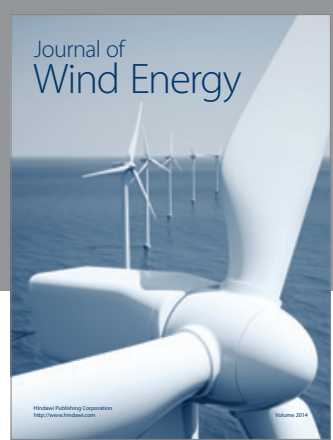

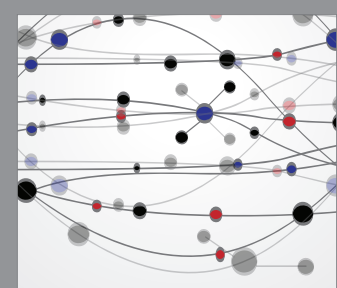

The Scientific World Journal

Submit your manuscripts at http://www.hindawi.com

Journal of

Structures
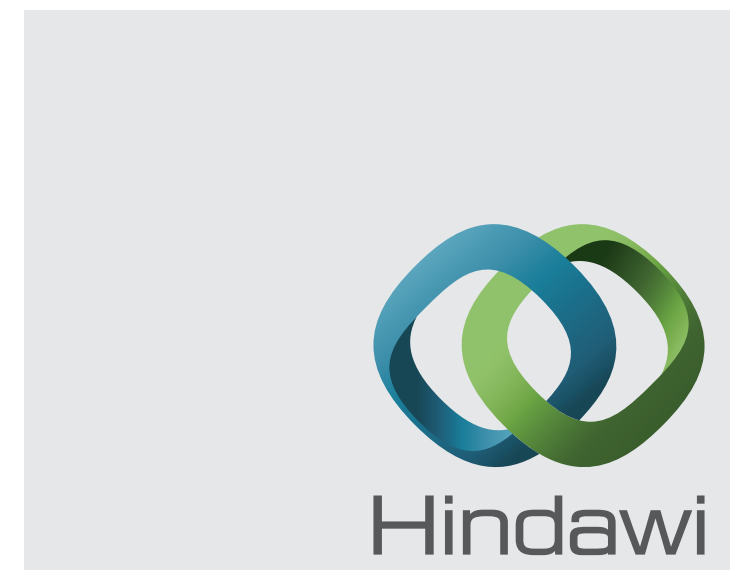

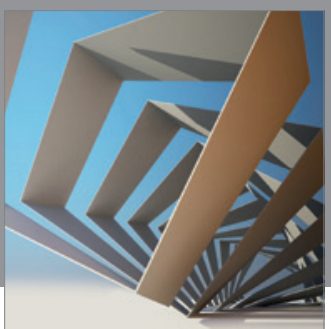

Rotating

Machinery
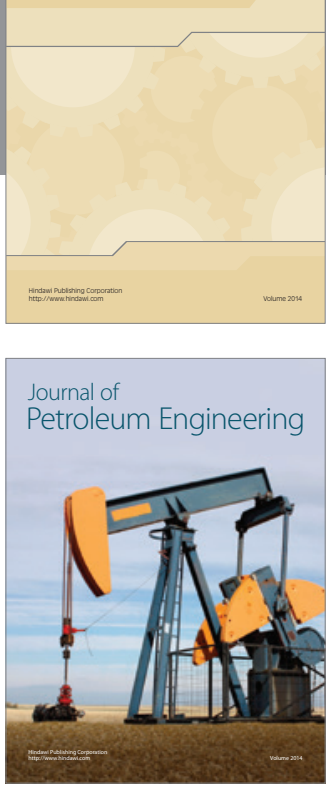

Journal of

Solar Energy
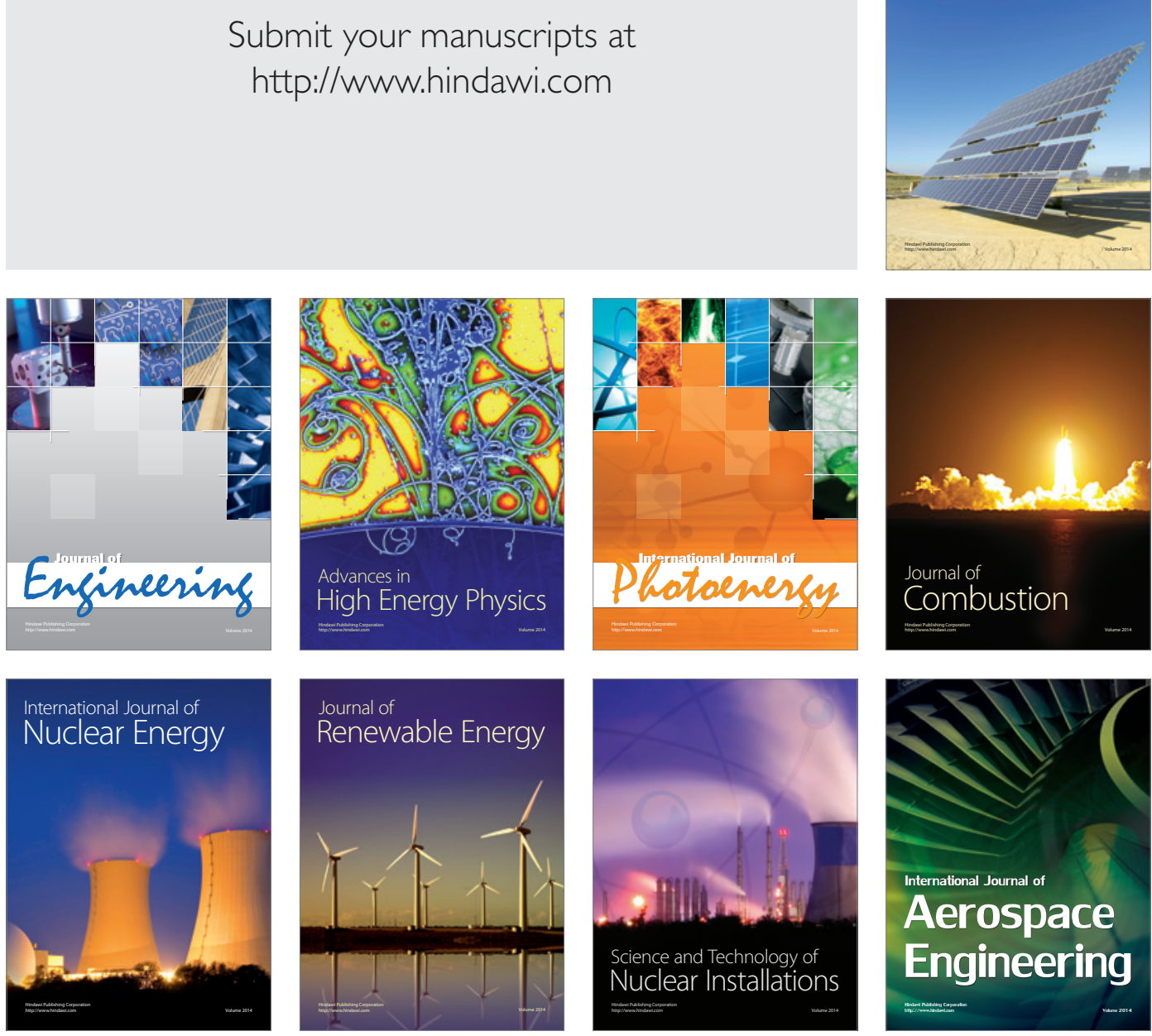